\title{
Strong increases in flood frequency and discharge of the River Meuse over the late Holocene: impacts of long-term anthropogenic land use change and climate variability
}

\author{
P. J. Ward ${ }^{1}$, H. Renssen ${ }^{1}$, J. C. J. H. Aerts ${ }^{2}$, R. T. van Balen ${ }^{1}$, and J. Vandenberghe ${ }^{1}$ \\ ${ }^{1}$ Institute of Earth Sciences, Faculty of Earth and Life Sciences, VU University Amsterdam, De Boelelaan 1085, $1081 \mathrm{HV}$ \\ Amsterdam, The Netherlands \\ ${ }^{2}$ Institute for Environmental Studies, Faculty of Earth and Life Sciences, VU University Amsterdam, De Boelelaan 1085, \\ 1081 HV Amsterdam, The Netherlands
}

Received: 1 August 2007 - Published in Hydrol. Earth Syst. Sci. Discuss.: 6 August 2007

Revised: 6 December 2007 - Accepted: 3 January 2008 - Published: 31 January 2008

\begin{abstract}
In recent years the frequency of high-flow events on the Meuse (northwest Europe) has been relatively great, and flooding has become a major research theme. To date, research has focused on observed discharge records of the last century and simulations of the coming century. However, it is difficult to delineate changes caused by human activities (land use change and greenhouse gas emissions) and natural fluctuations on these timescales. To address this problem we coupled a climate model (ECBilt-CLIO-VECODE) and a hydrological model (STREAM) to simulate daily Meuse discharge in two time-slices: 4000-3000 BP (natural situation), and 1000-2000 AD (includes anthropogenic influence). For 4000-3000 BP the basin is assumed to be almost fully forested; for 1000-2000 AD we reconstructed land use based on historical sources. For 1000-2000 AD the simulated mean annual discharge $\left(260.9 \mathrm{~m}^{3} \mathrm{~s}^{-1}\right)$ is significantly higher than for $4000-3000 \mathrm{BP}\left(244.8 \mathrm{~m}^{3} \mathrm{~s}^{-1}\right)$, and the frequency of large high-flow events (discharge $>3000 \mathrm{~m}^{3} \mathrm{~s}^{-1}$ ) is higher (recurrence time decreases from 77 to 65 years). On a millennial timescale almost all of this increase can be ascribed to land use changes (especially deforestation); the effects of climatic change are insignificant. For the 20th Century, the simulated mean discharge $\left(270.0 \mathrm{~m}^{3} \mathrm{~s}^{-1}\right)$ is higher than in any other century studied, and is ca. $2.5 \%$ higher than in the 19th Century (despite an increase in evapotranspiration). Furthermore, the recurrence time of large high-flow events is almost twice as short as under natural conditions (recurrence time decreases from 77 to 40 years). On this timescale climate change (strong increase in annual and winter precipitation) overwhelmed land use change as the dominant forcing mechanism.
\end{abstract}

Correspondence to: P. J. Ward

(philip.ward@falw.vu.nl)

\section{Introduction}

In recent years the frequency of high-flow events in the Meuse basin (northwest Europe) (Fig. 1) has been relatively great compared to the rest of the 20th Century. As a result, flooding and flood mitigation have become major research themes. Hence, numerous studies have been carried out to examine hydrological and climatological changes in the basin.

Observed discharge time-series for the Meuse at Borgharen (Fig. 1) show no significant changes in annual or monthly mean discharge over the 20th Century (Tu, 2006). However, increasing trends (albeit statistically insignificant) are detected for annual and winter maximum daily discharge (De Wit et al., 2001). Furthermore, change-point analyses suggest significant increases in annual and winter maximum daily discharge around 1984 (Pfister et al., 2000; Tu, 2006). Similar results are found for numerous Meuse tributaries $(\mathrm{Tu}$, 2006). This increase in the frequency of high-flow events may be related to an increase in annual precipitation totals and the frequency of very wet days in the winter since 1980, due to the fluctuation of large-scale atmospheric circulation (Bouwer et al., 2006) and a strengthened North Atlantic Oscillation ( $\mathrm{Tu}, 2006)$. Increased precipitation totals and intensity in the second half of the 20th Century, related to variations in atmospheric circulation, have been observed in the Netherlands and Luxembourg (Pfister et al., 2000).

Climate modelling results suggest that average temperatures and winter precipitation depths in the Meuse basin will increase in the 21 st Century, whilst summer precipitation will decrease (De Wit et al., 2007; Kwadijk and Rotmans, 1995; Pfister et al., 2004; Van Deursen, 2000). Based on hydrological modelling, De Wit et al. (2001) suggest that mean annual discharge will remain relatively stable over the 21 st Century, whilst Booij (2005) suggests a slight decrease. The seasonal

Published by Copernicus Publications on behalf of the European Geosciences Union. 


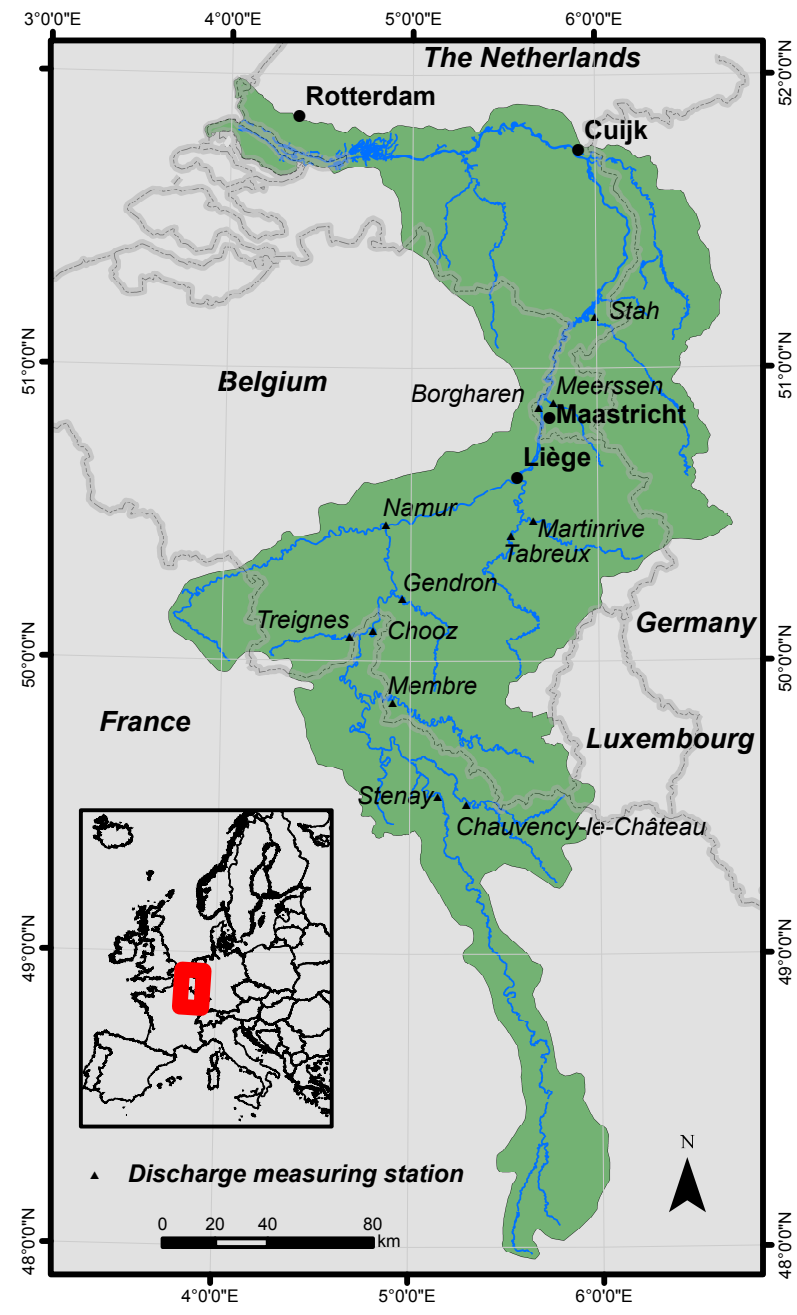

Fig. 1. Map showing the location of the Meuse Basin and discharge measuring stations used in this study (after RWS Limburg/IWACO, 2000). The basin has an area of ca. $33000 \mathrm{~km}^{2}$, and covers parts of France, Luxembourg, Belgium, Germany, and the Netherlands. The inset shows the location of the Meuse basin in Europe.

distribution of discharge may change so that winter discharge becomes greater and summer discharge lower (De Wit et al., 2007). These and other studies, however, suggest that the anticipated climate change of the 21st Century will lead to an increase in flood frequency (Bultot et al., 1988; Gellens and Roulin, 1998; Middelkoop and Parmet, 1998; Van Deursen, 2000).

Discharge, however, depends not only on climate but also on land use. Little research has been carried out to examine the effects of land use change in the basin because the forested area has remained relatively stable at the basin-scale over the last century (Knol et al., 2004; Tu, 2006). Ashagrie et al. (2006) and Tu (2006) found no evidence to suggest that land use changes in the 20th Century have had a significant effect on Meuse discharge.
The aforementioned studies have examined either the discharge changes of the last century, or used hydrological models calibrated against observations for that period. However, when studying long-term discharge changes this approach is problematic. Firstly, accurate daily measurements of Meuse discharge have only been made since 1911, which is too short to evaluate long-term climatic changes (Jones, 2000). Secondly, at a basin-scale the forested area has been relatively stable over the last century, making it difficult to assess the effects of large-scale changes in land use.

Palaeodischarge modelling provides a means to address the lack of long-term observed data by providing a dataset for the validation of model response on millennial timescales. This enables us to simulate the response of discharge to changes in climate over longer timescales, and to more extensive changes in land use. However, palaeodischarge modelling is in its infancy. For example, Coe and Harrison (2002) used runoff derived directly from a General Circulation Model (GCM), combined with a river routing algorithm, to simulate lake-level changes in Africa at ca. $6 \mathrm{ka} \mathrm{BP}$. At the basin-scale, however, the use of runoff derived directly from GCMs has a disadvantage as runoff output are less well resolved than climatic output. To address this problem, Aerts et al. (2006) and Ward et al. (2007) coupled a climate model and a hydrological model to simulate the Holocene discharge of 19 rivers around the globe on a monthly time-step; the modelled discharges correspond well with multi-proxy records of palaeodischarge.

The aim of this paper is to examine the sensitivity of Meuse discharge to long-term changes in Holocene climate and land use. This is achieved using the modelling approach of Aerts et al. (2006) and Ward et al. (2007), but with a daily time-step and higher spatial resolution. Meuse discharge is simulated for two time-slices: $4000-3000 \mathrm{BP}$ and $1000-2000 \mathrm{AD}$. The period $4000-3000 \mathrm{AD}$ is selected as a natural reference period since the natural climatic forcings were broadly similar to those of today, whilst human influence on land use was minimal (Bunnik, 1995; Gotjé et al., 1990; RWS Limburg/IWACO, 2000). The period 10002000 AD was heavily influenced by human activities, namely changes in land use throughout the period, and greenhouse gas emissions since the industrial revolution. By comparing the changes in discharge characteristics between these two situations we can examine the effects of anthropogenic changes in climate and land use.

\section{Study area}

The Meuse is a predominantly rain-fed river with a total length of ca. $875 \mathrm{~km}$. For this study the basin has been modelled upstream from Borgharen (Fig. 1).

Mean annual precipitation over the basin is ca. $950 \mathrm{~mm} \mathrm{a}^{-1}$, and is reasonably evenly distributed throughout the year. The spatial distribution of precipitation 
is to a large extent a reflection of elevation and distance from the coast. Mean temperatures show marked seasonal variations, and annual potential evapotranspiration is much greater in the summer half-year (May-October) than in the winter half-year (November-April) $(76 \%$ and $24 \%$ of the total respectively) (Ashagrie et al., 2006). The mean annual discharge of the Meuse and its associated canals at the border of Belgium and the Netherlands is ca. $276 \mathrm{~m}^{3} \mathrm{~s}^{-1}$; summer and winter half-year mean discharges are $146 \mathrm{~m}^{3} \mathrm{~s}^{-1}$ and $406 \mathrm{~m}^{3} \mathrm{~s}^{-1}$ respectively (Ashagrie et al., 2006).

\section{Methods and approach}

In this study we couple the climate model ECBilt-CLIOVECODE (Brovkin et al., 2002; Goosse and Fichefet, 1999; Opsteegh et al., 1998) with the hydrological model STREAM (Aerts et al., 1999) to simulate Meuse palaeodischarge. The hydrological model is run with a daily time-step and spatial resolution of $2^{\prime} \times 2^{\prime}$ (ca. $2.4 \mathrm{~km} \times 3.7 \mathrm{~km}$ ). In this section we present the main features of the model; for a more detailed discussion see Ward (2007).

\subsection{Models and climate forcing parameters}

ECBilt-CLIO-VECODE is a three-dimensional coupled climate model consisting of three components describing the atmosphere, ocean and vegetation (Brovkin et al., 2002; Goosse and Fichefet, 1999; Opsteegh et al., 1998). The output used in this study are derived from a transient run, forced by annually varying orbital parameters and atmospheric greenhouse gas concentrations $\left(\mathrm{CO}_{2}\right.$ and $\left.\mathrm{CH}_{4}\right)$ following Renssen et al. (2005), and atmospheric volcanic aerosol content and fluctuations in solar activity following Goosse et al. (2005). The model was run in ensemble mode, with 4 ensemble members. Each ensemble member represents a single model run. The ensemble members are forced using the same climatic parameters, but with slightly different initial climatic conditions to account for the chaotic behaviour of the atmospheric system. Hence, the difference between the ensemble members gives an idea of the natural variability, whereas an ensemble mean can be used to evaluate long-term trends.

STREAM is a grid-based spatially distributed water balance model that describes the hydrological cycle of a drainage basin as a series of storage compartments and flows (Aerts et al., 1999). It is based on the RHINEFLOW model of Kwadijk (1993), and uses a raster GIS database to calculate the water balance of each grid cell per time-step. The water balance is calculated using the Thornthwaite (1948) equations for potential evapotranspiration and the Thornthwaite and Mather (1957) equations for actual evapotranspiration; these equations use temperature and precipitation as the major input parameters. For each time-step the model generates runoff, groundwater storage (shallow and deep), snow cover,

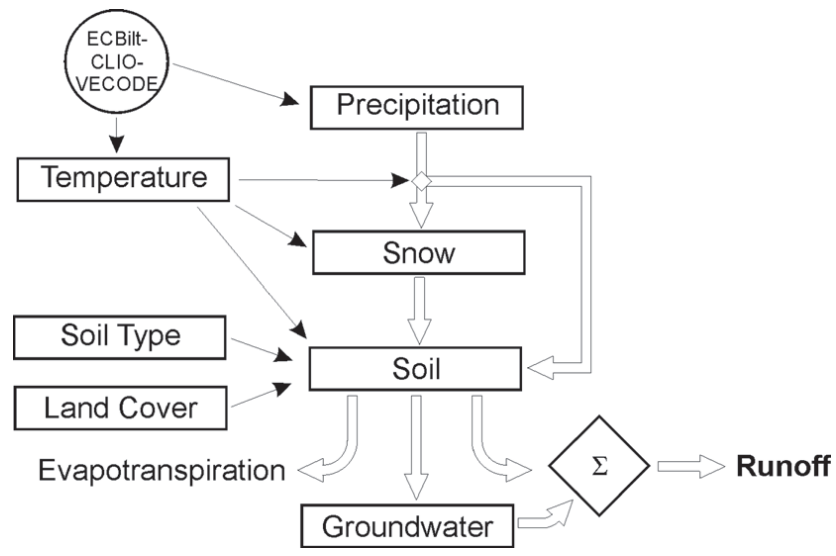

Fig. 2. Flowchart showing the main storage compartments and flows of the STREAM palaeodischarge model (Ward et al., 2007). STREAM is based on a raster GIS database and calculates the water balance of each grid cell per time-step using the Thornthwaite (1948) equations for potential evapotranspiration and the Thornthwaite and Mather (1957) equations for actual evapotranspiration. For each cell and time-step the model generates runoff, groundwater storage (shallow and deep), snow cover, and snow melt. The direction of water flow between cells is based on the steepest descent for the eight surrounding grid cells on a digital elevation model (DEM).

and snow melt. The direction of water flow between cells is based on the steepest descent for the eight surrounding grid cells on a digital elevation model (DEM). The main flows and storage compartments used to calculate water availability per cell are shown in Fig. 2. More detailed information, including the equations used in the calculation of the water balance, can be found in Ward (2007). The STREAM model was selected for numerous reasons (Ward, 2007). Firstly, as the model is based on a GIS database it can be used to examine the effects of spatial changes in land use. Secondly, the model contains relatively few calibration parameters, whilst retaining a simple physical grounding. The introduction of many parameters can increase model uncertainty, which is already necessarily high in palaeodischarge assessments due to the lack of measured discharge prior to the era of instrumental records. Thirdly, the model can be run on a daily time-step, which is essential when assessing flood frequency. Furthermore, the model is efficient to run in terms of computational time, which is especially important given the use of a daily time-step over periods of a millennium.

In this study, STREAM is run at a spatial resolution of $2^{\prime} \times 2^{\prime}$; this is high enough to capture the dominant processes in the basin (Booij, 2002), whilst pragmatic concerns regarding computational time render a higher resolution unfeasible. Since we will be running STREAM on a daily timestep, as opposed to the monthly or 10-day time-step used in previous applications, we have added a simple thresholdbased direct runoff component to simulate infiltration excess overland flow. When precipitation exceeds a threshold 

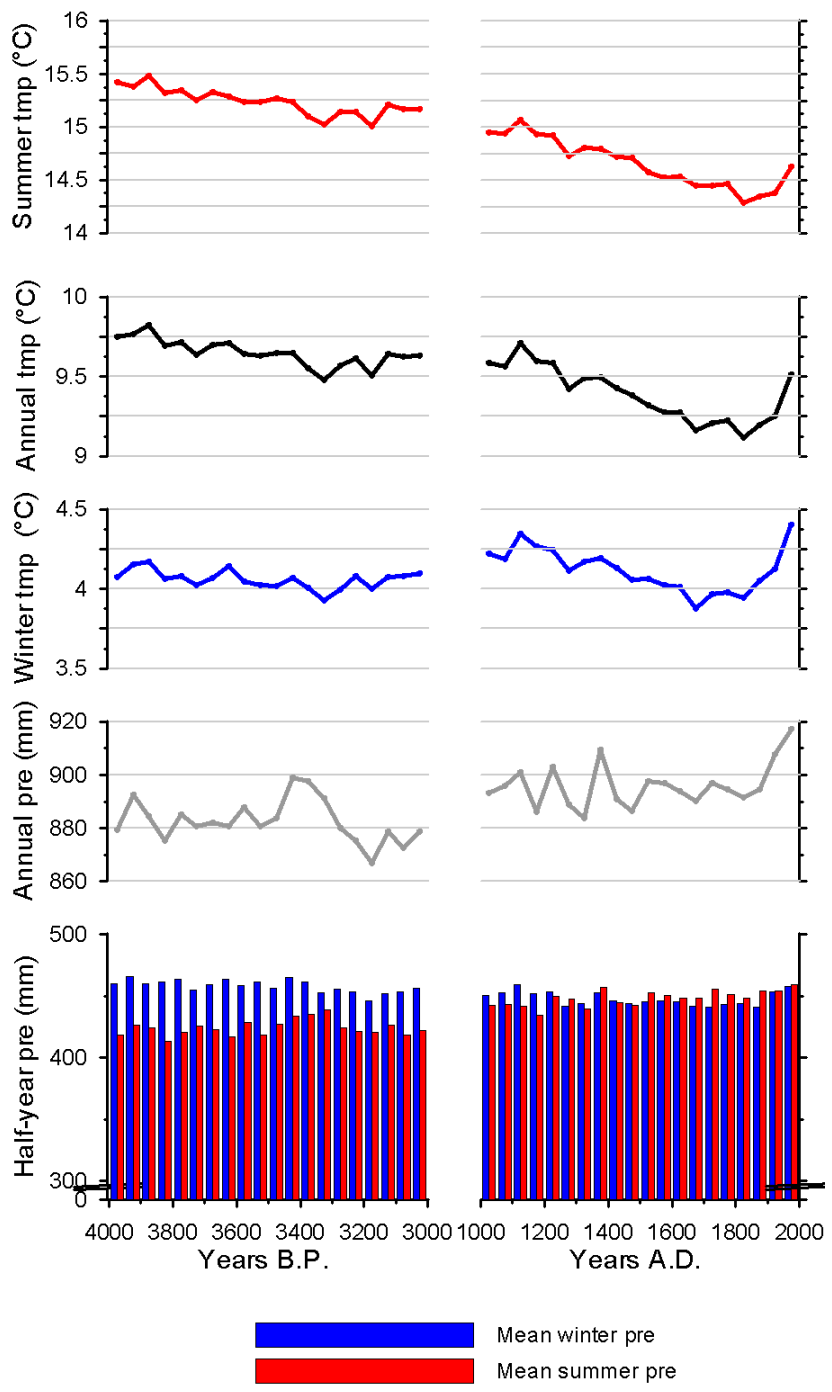

Fig. 3. Downscaled ECBilt-CLIO-VECODE climate data for the time-periods 4000-3000 BP and 1000-2000 AD. The means of the 4 ensemble members are shown for each 50-year period. The bar charts show summer and winter half-year precipitation (pre), whilst the lines show long-term changes in mean summer, annual, and winter temperature (tmp), and mean annual precipitation.

(Ward and Robinson, 1990), excess precipitation runs off regardless of whether the soil is saturated. Runoff is routed through the river network on a daily basis using data on average flow velocities stated in Berger (1992) (see Ward, 2007). The model was set up for the catchment upstream from Borgharen (Fig. 1), using the USGS GTOPO30 DEM (http: //edc.usgs.gov/products/elevation/gtopo30/gtopo30.html).

\subsection{Input data}

\subsubsection{Climate data}

The climate data (daily temperature and precipitation) derived from ECBilt-CLIO-VECODE have a spatial resolution of ca. $5.6^{\circ} \times 5.6^{\circ}$, and therefore need downscaling to the resolution of the STREAM model. The downscaling takes into account the spatial distribution of monthly averages, in accordance with Bouwer et al. (2004), using baseline observed monthly temperature and precipitation data for the period 1901-2000 from the CRU TS 1.2 dataset (Mitchell and Jones, 2005).

The downscaled mean monthly temperature and precipitation data for the period 1901-2000 show good agreement with observed values for all ensemble members (temperature, $r>0.99$; precipitation, $r>0.96$ ). The downscaled daily temperature data were validated against observed values for Maastricht, from the European Climate Assessment \& Dataset (ECA\&D) (http://eca.knmi.nl/) (Klein Tank et al., 2002). The modelled daily temperature data show good agreement with the observations (Mann-Whitney U test (MWU), $\alpha=0.05)$. The number of precipitation-free days at Maastricht (model, 27.5\%; observed, 45.7\%) is underestimated; this is related to the fact that the original model grid cell represents an area of ca. $5.6^{\circ} \times 5.6^{\circ}$, whilst the observed data refer to a specific point. We found no significant difference between the frequency distributions of observed and simulated daily precipitation for very wet days $(10 \%$ wettest days) (Kruskal-Wallis (KW) test, $\chi^{2}=1.691, p=0.792$ ).

Simulated mean annual precipitation for 1000-2000 AD $(895.93 \mathrm{~mm})$ is slightly but statistically higher than for 4000 $3000 \mathrm{BP}(882.56 \mathrm{~mm})(\mathrm{t}$-test, $p<0.001)$, though there is no statistical difference in variability (F-test, $p=0.291$ ) (Fig. 3). However, whilst mean summer precipitation for 1000$2000 \mathrm{AD}(448.22 \mathrm{~mm})$ is significantly higher than for 4000 $3000 \mathrm{BP}(424.37 \mathrm{~mm})$ (t-test, $p<0.001)$, winter precipitation is lower $(1000-2000 \mathrm{AD}, 447.71 \mathrm{~mm} ; 4000-3000 \mathrm{BP}$, $458.19 \mathrm{~mm}$; t-test, $p<0.001)$. The greatest precipitation increase is between July and September. Mean 50-yr precipitation shows neither a significant trend over the period 4000$3000 \mathrm{BP}$ (MK-test, $p=-0.1048$ ) nor over the last millennium (MK-test, $p=-0.2176$ ). For the period 1000-2000 AD, mean annual and summer temperatures $\left(9.39^{\circ} \mathrm{C}\right.$ and $14.66^{\circ} \mathrm{C}$ respectively) are significantly lower than for $4000-3000 \mathrm{BP}$ $\left(9.65^{\circ} \mathrm{C}\right.$ and $15.24^{\circ} \mathrm{C}$ respectively) (t-test, $p<0.001$ ). Over the course of the last millennium, mean, summer, and winter 50-yr temperatures show decreasing trends (MK-test, $p<0.001, p<0.001, p=0.004$ respectively), although clear increases are simulated over the last 150 years (Fig. 3). The long-term cooling trend of the late Holocene can be attributed to the biogeophysical effects of deforestation in (northwestern) Europe (Brovkin et al., 2006; Goosse et al., 2006; Matthews et al., 2003). For the 20th Century, mean simulated annual precipitation is $912.40 \mathrm{~mm}$, and temperature is 
$9.38^{\circ} \mathrm{C}$; both show a relatively large increase in the second half of the 20th Century. Precipitation depths on very wet days (95th and 99th percentiles) are greater during 40003000 BP than 1000-2000 AD. Although these precipitation depths increased in the 20th Century compared to the rest of the last millennium, they are still lower than at 4000 $3000 \mathrm{BP}$.

\subsubsection{Land use data}

A crop factor map is used in STREAM to calculate potential evapotranspiration (PE). The crop factor is a dimensionless factor by which the reference PE is multiplied in order to account for the difference in PE over different land use types. In this study we have developed a land use map for each century (Appendix A); for more detailed information see Ward (2007). For the period 1000-2000 AD the pattern of land use change is shown in Fig. 4. The land use classes have been simplified due to the relative scarcity of detailed historical land use data, and reclassed to crop factor maps based on values in Kwadijk (1993) and Aerts and Bouwer (2002): Urban (0.8), Forests (1.1), Agriculture and Grasslands (0.9), Wetlands (1.1), Water Bodies (1.5).

For the 20th Century, we used the dataset CORINE Land Cover 2000 (CLC2000) $250 \mathrm{~m}$ version 8/2005 (V2) (C EEA, Copenhagen, 2005), available at http://dataservice.eea.eu.int/ dataservice/. For the 19th Century we used data on forest and urban area from historical census information for Belgium (WL, 1994a) and France (Dutoo, 1994), and from historical maps for the Netherlands (Knol et al., 2004). Data on wetlands and peat bogs were based on RWS Limburg/IWACO (2000). For the 11th Century we used a map of Meuse basin land use at ca. $1000 \mathrm{AD}$ (RWS Limburg/IWACO, 2000), based on historical and archaeological evidence. For the remaining centuries (12th-18th Centuries) no quantitative assessments of land use are available; instead the land use maps are based on qualitative historical studies (RWS Limburg/IWACO, 2000; WL, 1994a) and linear extrapolation (Ward, 2007).

Although archaeological and pollen evidence suggest that parts of the basin were populated by 4000-3000 BP (Bunnik, 1995; Gotjé et al., 1990; Henrard, 2003), any disturbance in this period was, in our opinion, minor, and too small to have had any significant influence on hydrological processes (see results of sensitivity analysis in Sect. 3.4). Since the natural vegetation of northwest Europe at that time was predominantly deciduous forest (Bunnik, 1995; Gotjé et al., 1990), we have assumed a fully forested basin at 4000-3000 BP, except for those cells referring to "Water Bodies" (CORINE), and "Wetlands" (RWS Limburg/IWACO, 2000).

The basin-averaged crop factor (Fig. 5) shows a marked reduction between 4000-3000 BP and 1000-2000 AD (conversion of forest to agriculture), and decreases further over the last millennium (deforestation and peat extraction). However, in the 20th Century the crop factor increases slightly

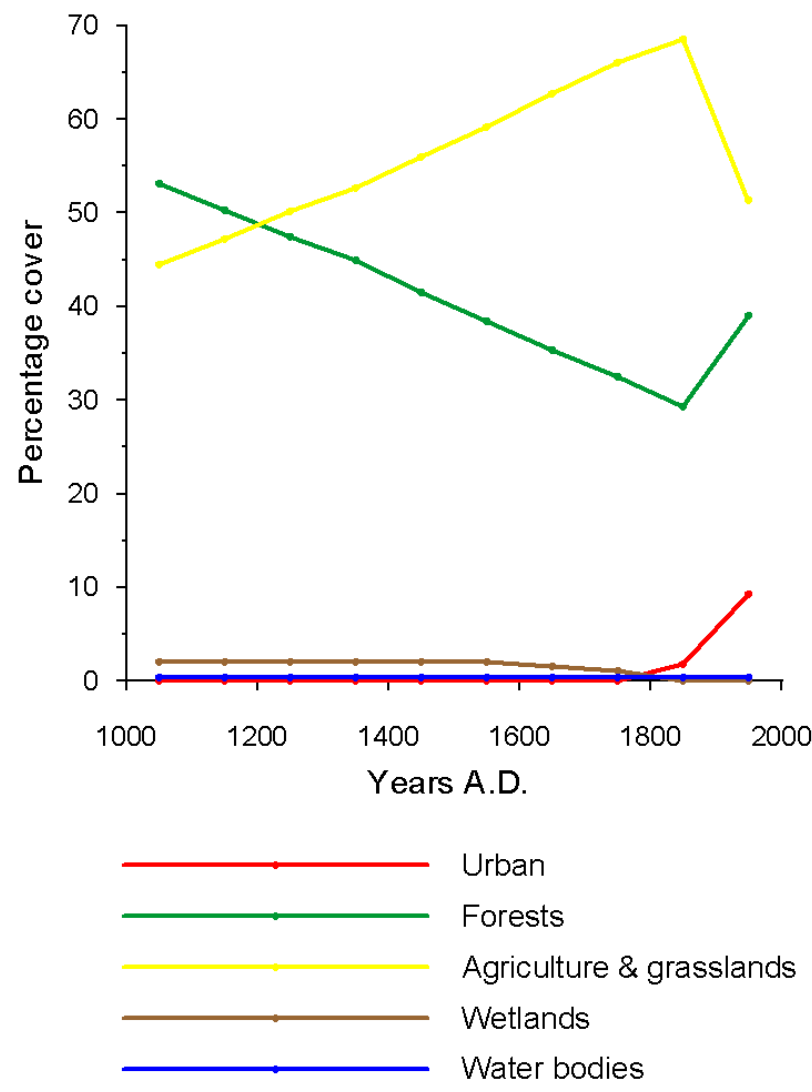

Fig. 4. Estimations of Meuse basin land use upstream from Borgharen during the period 1000-2000 AD. Forest cover fell from ca. $53 \%$ at the beginning of the last millennium to ca. $29 \%$ in the 19th Century, mainly at the expense of agricultural land. Between the 19th and 20th Centuries the percentage cover of forest and urban area increased at the expense of agricultural land.

(due to the reforestation of previously cultivated land, although tempered by urbanisation). Changes in land cover (the physical characteristics of the Earth's surface) have shown more change than land use over the last century (e.g. an increase in coniferous forest relative to deciduous forest, and changes in types of agriculture) (Tu, 2006). However, on a millennial timescale the large-scale changes in land use are more important than such changes.

\subsubsection{Soil water holding capacity}

A map showing the maximum water holding capacity (WHC) of the soil $\left(\mathrm{mm} \mathrm{m}^{-1}\right)$ is used in STREAM to calculate evapotranspiration, runoff, groundwater seepage, and baseflow. For the present day we have used the United $\mathrm{Na}-$ tions Food and Agriculture Organization's (FAO) map of WHC (FAO, 2003). Since the FAO dataset has too coarse a resolution to accurately represent the remaining areas of peat-bog in the Meuse basin, we have assigned those areas a value of $71 \mathrm{~mm} \mathrm{~m}^{-1}$, i.e. the modal WHC value for 


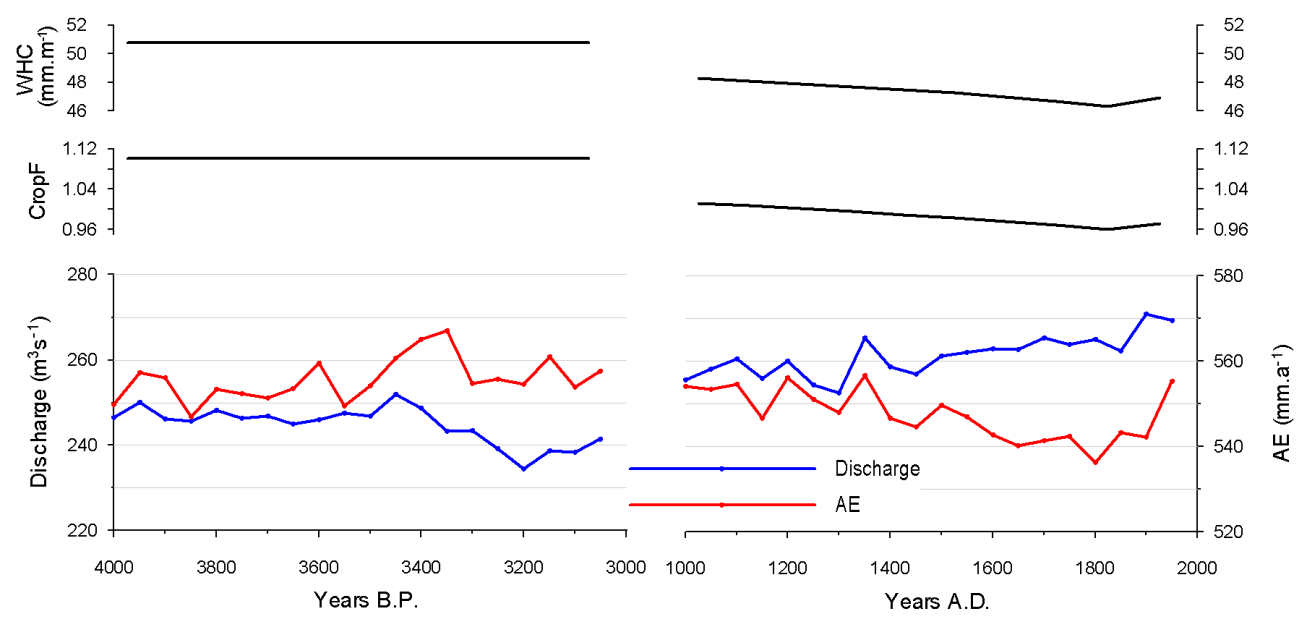

Fig. 5. Changes in mean annual discharge at Borgharen, basin-wide mean annual actual evapotranspiration (AE), crop factor (CropF), and soil water holding capacity (WHC). For discharge and AE the mean values of the 4 ensemble members are shown, and have been lumped into 50-year periods in order to show the long-term signal. The crop factor reflects changes in basin-averaged land use, and shows a decrease over the last 1000 years due to deforestation, and an increase over the last 100 years due to reforestation. The changes in WHC are related to changes in land cover.

the remaining large intact areas of European peat-bog (FAO, 2003). Changes in land use cause changes in soil textural properties, therefore influencing WHC. The FAO WHC map is based on dominant soil unit, component soil units, texture, soil phase, and relief, but does not explicitly consider vegetation. We found a significant positive correlation between WHC and percentage forest cover between the various soil units, and a significant negative correlation between WHC and percentage cover of agriculture and grasslands (Spearman's rank, $\alpha=0.05$ ). Hence, the percentage difference between the mean WHC of soils covered by forests and those covered by agriculture and grasslands was calculated, and the resulting change factors were coupled with the land use anomalies over time, to produce WHC maps for each century, similar to Mahe et al. (2005). For areas covered by rendzinas (shallow humus-rich soils over limestone) the original WHC of $63 \mathrm{~mm} \mathrm{~m}^{-1}$ was retained since the WHC of this soil unit is mainly influenced by parent material (FAO, 2003). The estimated change in basin-wide WHC over the late Holocene can be seen in Fig. 5. Given the uncertainties in the spatial distribution of land use over the Holocene, the input maps of WHC give only an indication of the situation in each period, but the sign of change at the basin scale is in agreement with the gradual decrease in WHC at the basin scale over the late Holocene (e.g. RWS Limburg/IWACO, 2000).

\subsection{Calibration and validation}

Calibration was carried out for the relatively wet period 1961-2000, and validation for the relatively dry period 1921-1960. The calibration was initially carried out for the main river at Borgharen, using data provided by Rijkswaterstaat RIZA (Institute for Inland Water Manage- ment and Waste Water Treatment), pertaining to the "undivided Meuse"; they are based on discharge measurements at Borgharen, corrected for canal extractions between Liège and Borgharen (De Wit et al., 2007), and are available since 1911. Further stations on the main river body were obtained for Chooz (Berger, 1992), and Stenay (DIREN Lorraine Bassin Rhin-Meuse). Tributary data were obtained from: Direction Générale des Voies Hydrauliques Region Wallonne (http://voies-hydrauliques. wallonie.be/opencms/opencms/fr/hydro/annuaires/) for the Chiers (Chauvency-le-Château), Semois (Membre), Lesse (Gendron) Amblève (Martinrive), Ourthe (Tabreux), and Viroin (Treignes); Roer and Overmaas Water Board for the Geul (Meerssen) and Roer (Stah); and Berger (1992) for the Sambre (Namur). The parameters used in the final model can be found in Ward (2007).

The annual hydrographs for Borgharen (Fig. 6) show good correlations between mean annual and mean monthly modelled and observed discharges for the calibration and validation periods, as well as for both periods taken together. The agreement of total annual discharge was assessed by expressing mean annual modelled discharge as a percentage of mean annual observed discharge (\%), and the correlation of the means of monthly discharge was assessed using the correlation coefficient, $r$, and the co-efficient of efficiency, N\&S. The modelled and observed daily discharge frequency distributions for 1921-2000 are statistically similar (MWU-test, $p=0.366)$. In Table 1 the mean annual $k$ th percentiles are given for the calibration and validation runs $(k=1,25,50,75$, $90,95,99)$, showing good agreement for low, average, and high-flows. The model slightly overestimates the frequency of summer half-year high-flows $\left(Q_{k}, k>97\right)$ due to an over- 
Table 1. Magnitudes of mean annual $k$ th percentiles of daily discharge $\left(Q_{k}, k=1,25,50,75,90,95,99\right)$ at Borgharen for the calibration and validation periods. Bold type indicates that the magnitudes are statistically similar to the observed discharge magnitudes (t-test, $\alpha=0.05$ ).

\begin{tabular}{lccccccc}
\hline & \multicolumn{7}{c}{ Discharge $\left(\mathrm{m}^{3} \mathrm{~s}^{-1}\right)$} \\
\hline Time-period & $Q_{1}$ & $Q_{25}$ & $Q_{50}$ & $Q_{75}$ & $Q_{90}$ & $Q_{95}$ & $Q_{99}$ \\
\hline Calibration (1961-2000) & $\mathbf{4 7 . 5}$ & $\mathbf{9 3 . 2}$ & $\mathbf{1 8 5 . 9}$ & $\mathbf{3 8 0 . 4}$ & $\mathbf{6 0 7 . 9}$ & $\mathbf{7 5 4 . 9}$ & $\mathbf{1 0 9 6 . 2}$ \\
Validation (1921-1960) & $\mathbf{4 6 . 9}$ & $\mathbf{9 1 . 1}$ & $\mathbf{1 7 8 . 6}$ & $\mathbf{3 7 9 . 2}$ & 623.1 & $\mathbf{7 7 4 . 7}$ & $\mathbf{1 1 6 5 . 7}$ \\
\hline
\end{tabular}

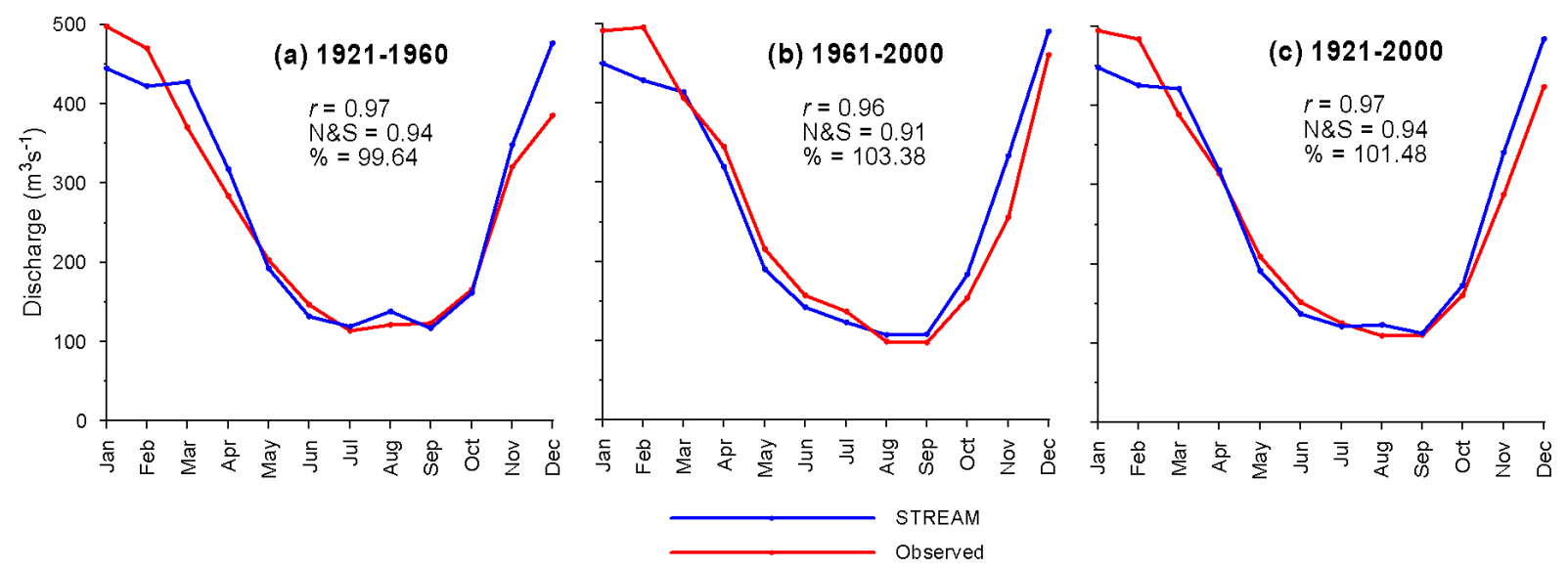

Fig. 6. Hydrographs showing the agreement between mean monthly simulated and observed discharge at Borgharen for: (a) the validation period, 1921-1960; (b) the calibration period, 1961-2000; and (c) the entire period 1921-2000. Also shown are the total accuracy (\%), Pearson's Product Moment Correlation Coefficient $(r)$, and Nash \& Sutcliffe efficiency (N\&S).

estimation of high precipitation events in autumn in ECBiltCLIO-VECODE. The model simulates the annual, monthly, and daily discharge characteristics of major tributaries well (Ward, 2007).

For the Meuse basin, no detailed estimates of actual evapotranspiration (AE) are available. The simulated mean annual basin-average potential evapotranspiration (PE) for 1921$2000\left(605 \mathrm{~mm} \mathrm{a}^{-1}\right)$ is of the same order of magnitude as the estimated PE for the Belgian sub-catchments for 19681998 (555 $\mathrm{mm} \mathrm{a}^{-1}$ ) (Leander et al., 2005), although the discrepancy is significant. However, in our model PE is converted into AE using the Thornthwaite and Mather (1957) equations, and whilst a discrepancy exists between modelled and "observed" PE this is not the case for AE. For the period 1901-2000 we simulate basin-wide precipitation of $912.7 \mathrm{~mm} \mathrm{a}^{-1}$, compared to $913.3 \mathrm{~mm} \mathrm{a}^{-1}$ in the observed (CRU) record; for mean annual discharge at Borgharen for the period 1921-2000 we simulated $268.4 \mathrm{~m}^{3} \mathrm{~s}^{-1}$, against $270.4 \mathrm{~m}^{3} \mathrm{~s}^{-1}$ in the observed record. Given that the annual values for soil storage, groundwater storage, and snow storage (i.e. the storage compartments of STREAM) remain constant over these periods, the mean annual AE total must also be correct. The correlation between mean monthly PE totals reflects the annual pattern of changes in PE well $(r=0.92)$.
Another approach to the simulation of evapotranspiration would have been to use PE and AE values from ECBiltCLIO-VECODE. However, no accurate datasets pertaining to these parameters are available for downscaling the climate model output to the resolution of STREAM.

Data pertaining to the number of days per year on which the ground is covered by snow at Maastricht (Klein Tank et al., 2002, http://eca.knmi.nl/), were used in the calibration of parameters pertaining to snowmelt and snowfall. In the model output for 1961-2000 the ground was covered by snow at Maastricht on average 3.6\% of days per year, compared to $3.7 \%$ of days in the observed record.

\subsection{Sensitivity analysis}

To assess the sensitivity of the hydrological model to changes in the calibration parameters, the model was re-run for the calibration period (1961-2000), but altering the values of individual calibration parameters by $\pm 10 \%$ and $\pm 50 \%$. The results of the sensitivity analysis can be found in Appendix B. The model is sensitive to changes in parameters influencing evapotranspiration (namely crop factor), and fairly insensitive to parameters pertaining to WHC and slope (C). Hence, it is important that the crop factors are reliable, as incorrect 


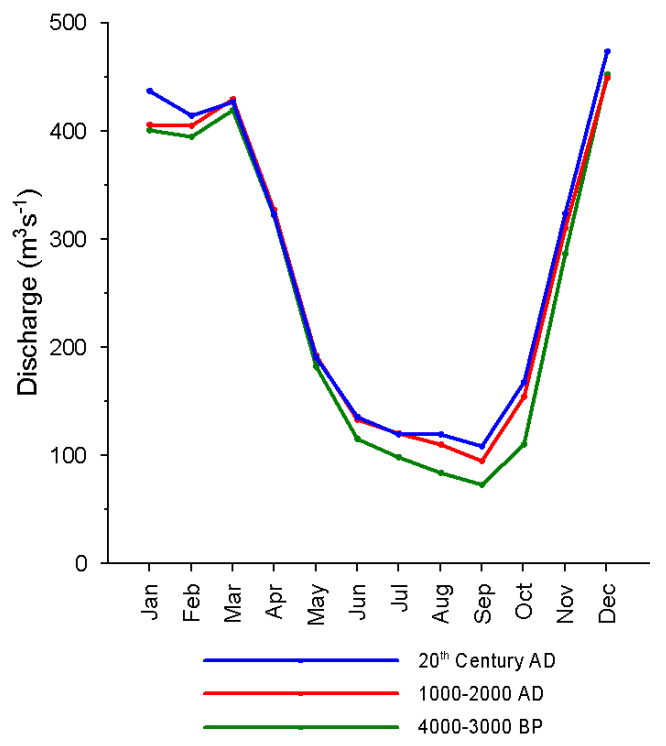

Fig. 7. Mean monthly simulated ensemble mean discharge at Borgharen for the periods 4000-3000 BP, 1000-2000 AD, and the 20th Century AD. The increase in discharge since the period 4000$3000 \mathrm{BP}$ has mainly taken place during the summer half-year.

crop factors could lead to large errors in the estimation of evapotraspiration. We calculated the present day percentage cover of forest and agriculture for 11 sub-catchments (upstream from the following points): Stenay, Chauvency-leChâteau, Membre, Gendron, Martinrive, Meerssen, Chooz, Tabreux, Stah, Namur, Treignes. For each sub-catchment we also calculated the percentage anomaly between annual observed and modelled discharge. We found no correlation between percentage forest cover and model accuracy (Spearman's Rank, $p=0.467)$, which suggests that the accuracy of the model is not biased by the crop factor values used for forest and agriculture. Since the main land use changes of the late Holocene have been between these two land use types, the model should therefore be able to simulate the effects of these land use changes on evapotranspiration.

The basin-wide changes in WHC used in our model (Fig. 5) show a maximum change between the periods 4000$3000 \mathrm{BP}$ and $1000-2000 \mathrm{AD}$ of $8.9 \%$. The sensitivity analysis showed that an increase or decrease of WHC of $10 \%$ led to a change in mean annual discharge of just $\pm 0.7 \%$, and had little influence on high and low-flows. Hence, our palaeodischarge model is more useful for examining the effects of land use change on evapotranspiration, rather than on soil moisture.

We also tested the sensitivity of the model to changes in land use (and namely the replacement of forest by agriculture) in order to firstly test our assumption that the small scale presence of humans in the Meuse basin during the period 4000-3000 BP would not have had a significant effect on hydrological processes, and secondly to test the robust- ness of our generalised maps of land use change. A control run was carried out using the climate data of one ensemble member for the period 4000-3000 BP, assuming the basin to be fully forested (except for those cells pertaining to wetlands, see Appendix A). Then, the model was re-run using the same climate data, but replacing the land use maps with new maps showing 5\% and 10\% deforestation respectively (forest cells were chosen at random and replaced by cells pertaining to agriculture). The results for mean annual and maximum discharge, as well as a number of discharge percentiles, are shown in Table 2. The slight increase in mean annual discharge between control and 5\% deforestation $(+0.8 \%)$ is statistically insignificant (t-test, $p=0.27)$, and the effect on high flows is very small. For a deforestation of $10 \%$, the effect on mean discharge $(+1.6 \%)$ becomes statistically significant (t-test, $p=0.03$ ), although it is still minor; the increase in mean annual maximum discharge $(+0.4 \%)$ is negligible. Given that the effects of a 5\% and $10 \%$ deforestation on our mid-Holocene discharge results are so minor, our assumption that land use at that time can be simulated using a scenario of full forest cover is valid. Furthermore, the results of our sensitivity analysis suggest that our generalised maps of land use change over time are robust, since the model is not oversensitive to small changes, and hence very detailed land use maps are not required.

\section{Results}

In this section we compare the results for 4000-3000 BP with those for 1000-2000 AD. We use the period 4000-3000 BP as a reference period in which the hydrological system was in a natural state. The discharge results for this reference period are compared to those of 1000-2000 AD, during which time the hydrological system was affected by anthropogenic changes in land use and climate.

\subsection{Mean discharge}

The simulated ensemble mean annual discharge shows a statistically significant increase (t-test, $p<0.001$ ) of $6.6 \%$ between 4000-3000 BP $\left(244.8 \mathrm{~m}^{3} \mathrm{~s}^{-1}\right)$ and 1000-2000 AD $\left(261.0 \mathrm{~m}^{3} \mathrm{~s}^{-1}\right)$ (Fig. 5). The variability of mean annual discharge also increased (4000-3000 BP, $\sigma=39.6$; 1000 $2000 \mathrm{AD}, \sigma=44.8$; F-test, $p<0.001)$. The increase in the winter half-year $(+2.3 \%)$ was small compared to the increase in the summer half-year $(+21.6 \%)$ (Fig. 7). Reference to Fig. 5 shows that discharge in the 20th Century AD (ca. $270.0 \mathrm{~m}^{3} \mathrm{~s}^{-1}$ ) was higher than in the period 1000-1900 AD, and that mean annual discharge in the period 1000-1900 AD (ca. $260.0 \mathrm{~m}^{3} \mathrm{~s}^{-1}$ ) was significantly higher than in the period 4000-3000 $\mathrm{BP}$ (t-test, $p<0.001$ ). The same is not true for the interannual variability, which shows no significant difference between 1000-1900 AD $(\sigma=44.7)$ and 1901$2000 \mathrm{AD}(\sigma=45.1)$ (F-test, $p=0.544)$. During the period 
Table 2. Sensitivity analysis of the coupled climate-hydrological model to changes in land use from forest to agriculture. The model was run for the period 4000-3000 BP assuming the basin to be fully forested (control), and then re-run assuming scenarios of 5\% and $10 \%$ deforestation respectively (forest replaced randomly by agriculture). The increases in mean $\left(Q_{\text {ann }}\right)$ and maximum $\left(Q_{\text {max }}\right)$ annual discharge as well as various mean annual $k$ th percentiles of daily discharge $\left(Q_{k}, k=25,50,75,90,95\right)$ show that a deforestation of $5 \%$ has little effect on Meuse discharge.

\begin{tabular}{lccccccc}
\hline & \multicolumn{7}{c}{ Discharge $\left(\mathrm{m}^{3} \mathrm{~s}^{-1}\right)$} \\
\hline Scenario & $Q_{\text {ann }}$ & $Q_{25}$ & $Q_{50}$ & $Q_{75}$ & $Q_{90}$ & $Q_{95}$ & $Q_{\max }$ \\
\hline Control (Full forest) & 241.3 & 65.8 & 144.0 & 342.6 & 572.1 & 726.5 & 1632.4 \\
5\% deforestation & 243.2 & 67.0 & 146.5 & 345.2 & 574.5 & 728.8 & 1635.7 \\
10\% deforestation & 245.2 & 68.3 & 149.2 & 347.9 & 576.8 & 731.1 & 1639.0 \\
\hline
\end{tabular}

1000-2000 AD, discharge shows an increasing monotonic trend (MK-test, $p<0.001$ ) (Fig. 5). Surplus water availability for runoff is in fact dependent on two key components: precipitation and actual evapotranspiration (AE). The long-term changes in discharge cannot be simply related to changes in precipitation over the Holocene. The simulated increase in summer precipitation between 4000-3000 BP and 1000-2000 AD was just 5.6\% (compared to a $21.6 \%$ increase in summer discharge), whilst winter precipitation depths showed a decrease of $2.3 \%$ (compared to a $2.3 \%$ increase in winter discharge). Moreover, no monotonic trend of increasing annual precipitation is simulated for the last millennium, in contrast to mean annual discharge. However, simulated AE was significantly higher at 4000-3000 BP than at 10002000 AD (t-test, $p<0.001)$. Furthermore, we see a strong decreasing trend in AE over the last 1000 years (MK-test, $p=0.004$ ) (Fig. 5), mainly as a result of reduced forest cover and hence reduced crop factor, and to a less extent due to reduced temperature.

We found no simple correlation relating mean annual temperatures to mean discharge or precipitation. Whilst we did simulate a strong positive correlation between 50-yr mean annual discharge and 50-yr summer precipitation totals for the period 1000-2000 AD, no such correlation was noted for 4000-3000 BP. Due to the higher crop factors at 4000$3000 \mathrm{BP}$, annual PE-AE at that time was almost two times as high as during the last millennium. Hence, more excess precipitation in wet summers could be lost to AE, and therefore fluctuations in summer precipitation had less influence on discharge. This mechanism may also be responsible for the simulated increase in variability of mean annual discharge, since no change in precipitation or temperature variability was simulated between the time-slices.

For the 20th Century we see an increase in mean discharge compared to the 19th Century (Fig. 5) (19th Century, $263.5 \mathrm{~m}^{3} \mathrm{~s}^{-1}$; 20th Century, $\left.270.0 \mathrm{~m}^{3} \mathrm{~s}^{-1}\right)$, despite a significant increase in AE (19th Century, $539.8 \mathrm{~mm} \mathrm{a}^{-1}$; 20th Century, $548.8 \mathrm{~mm} \mathrm{a}^{-1}$ ). This increase in discharge is ascribable to a relatively large increase in precipitation in the 20th Century (912.4 $\mathrm{mm} \mathrm{a}^{-1}$ ) compared to the 19th Century

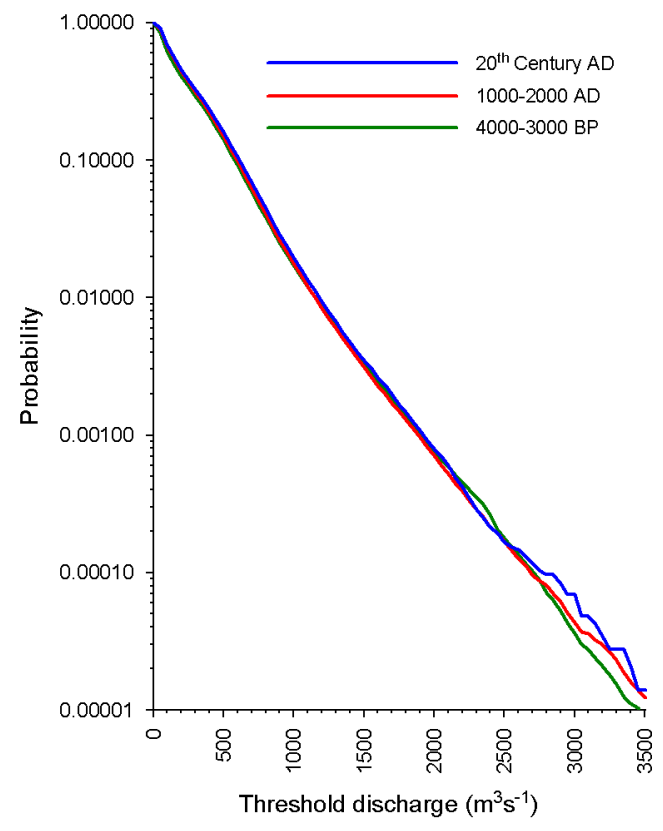

Fig. 8. Probability of daily discharge over a threshold for the 4 ensemble members. Large high-flow events $\left(Q>3000 \mathrm{~m}^{3} \mathrm{~s}^{-1}\right)$ are predicted more frequently in the period 1000-2000 AD than in the period 4000-3000 BP. In the 20th Century AD the frequency of large high-flow events is greater still.

(893.1 $\left.\mathrm{mm} \mathrm{a}^{-1}\right)$; annual precipitation depths in the former period are thereby greater than in any preceding century.

\subsection{High-flow events}

Between 4000-3000 BP and 1000-2000 AD the frequency of high-flows increased, whilst high-flows occurred even more frequently in the 20th Century $\mathrm{AD}$ than in the rest of the last millennium (Fig. 8). The difference between the frequency distributions for the periods 4000$3000 \mathrm{BP}$ and 1000-2000 AD is statistically significant (KStest, $p<0.001$ ), as are the differences between the frequency distributions between the periods 4000-3000 BP and 1000- 
Table 3. Simulated recurrence times of daily discharge $(Q)$ in excess of $800,1300,1950$, and $3000 \mathrm{~m}^{3} \mathrm{~s}^{-1}$; these discharge magnitudes correspond approximately to discharge percentiles $Q_{95}$, $Q_{99}, Q_{99.9}$, and $Q_{99.995}$ respectively, in the observed timeseries for Borgharen between 1912-2000. Large high-flow events $\left(Q>3000 \mathrm{~m}^{3} \mathrm{~s}^{-1}\right)$ are simulated almost twice as frequently in the 20th Century AD as in the natural reference period (4000-3000 BP).

\begin{tabular}{lcccc}
\hline & \multicolumn{4}{c}{ Discharge $\left(\mathrm{m}^{3} \mathrm{~s}^{-1}\right)$} \\
\hline Time period & $>800$ & $>1300$ & $>1950$ & $>3000$ \\
\hline 4000-3000 BP & 26 days & 165 days & 3.2 years & 77 years \\
1000-2000 AD & 25 days & 168 days & 3.4 years & 65 years \\
20th Century AD & 22 days & 150 days & 3.0 years & 40 years \\
\hline
\end{tabular}

$1900 \mathrm{AD}$, and 1000-1900 AD and 1901-2000 AD respectively (K-S test, $p<0.001$ ).

We examined the changes in the simulated recurrence times of high-flow events of the following magnitudes: $Q>800 \mathrm{~m}^{3} \mathrm{~s}^{-1}, 1300 \mathrm{~m}^{3} \mathrm{~s}^{-1}, 1950 \mathrm{~m}^{3} \mathrm{~s}^{-1}$, and $3000 \mathrm{~m}^{3} \mathrm{~s}^{-1}$ (Table 3). These correspond approximately to the discharge percentiles $Q_{95}, Q_{99}, Q_{99.9}$, and $Q_{99.995}$ in the observed record at Borgharen (1912-2000). Little change is evident in the recurrence times of relatively small to medium high-flows $\left(Q>800 \mathrm{~m}^{3} \mathrm{~s}^{-1}\right.$ and $\left.1300 \mathrm{~m}^{3} \mathrm{~s}^{-1}\right)$ between $4000-3000 \mathrm{BP}$ and 1000-2000 AD, although there is a slight but clear increase in frequency with regards to the 20th Century. For large high-flow events $\left(Q>3000 \mathrm{~m}^{3} \mathrm{~s}^{-1}\right)$, a clear increase in recurrence frequency can be seen between 4000-3000 BP and 1000-2000 AD, with a further increase in the 20th Century. The recurrence time of flows of this magnitude is almost twice as short in the 20th Century as in the reference period 4000-3000 BP. We also calculated the magnitude of highflows with an extremely long return period (1250 years): this increased from $4007 \mathrm{~m}^{3} \mathrm{~s}^{-1}$ in the period $4000-3000 \mathrm{BP}$, to $4143 \mathrm{~m}^{3} \mathrm{~s}^{-1}$ in the period 1000-2000 AD. For the 20th Century it was not possible to estimate the magnitude of highflows with this return frequency, since only 400 years of simulations (100 years $\times 4$ ensemble members) are available.

To examine whether the simulated number of large highflow events $\left(Q>3000 \mathrm{~m}^{3} \mathrm{~s}^{-1}\right)$ for the 20th Century falls within the limits of natural variability, we calculated the number of flow events for which $Q>3000 \mathrm{~m}^{3} \mathrm{~s}^{-1}$ for each possible 100 -yr period in the simulations. Note that the results of the 4 ensemble members have been lumped together, and hence each 100-year period corresponds to 400years of observations. Firstly, we filtered out flow events of $Q>3000 \mathrm{~m}^{3} \mathrm{~s}^{-1}$ whereby the simulated discharges occurred within 10 days of each other, so as to ensure that independent events were counted, following Tu (2006). For the period 1901-2000 AD, 10 flow events with $Q>3000 \mathrm{~m}^{3} \mathrm{~s}^{-1}$ were simulated in the 4 ensemble runs. Then we calculated the number of flow events for which $Q>3000 \mathrm{~m}^{3} \mathrm{~s}^{-1}$ for every possible $100-\mathrm{yr}$ period in the simulations; 900 possible periods of 100-yr duration exist for each millennial time-slice. During 1000-2000 AD, there were 8 periods of 100-yr duration in which this frequency of high-flow events (10 per 100 -yr for $Q>3000 \mathrm{~m}^{3} \mathrm{~s}^{-1}$ ) was simulated; for the period 4000-3000 BP it was simulated only one time. Hence, the frequency of large high-flows has been particularly great over the last 100 years, but does not fall outside natural variability.

\subsection{0th Century trends}

We investigated the presence or absence of monotonic trends (M-K test) in simulated discharge, precipitation, temperature, and AE time-series over the 20th Century. On this timescale land use is assumed to be constant in our model, so any trend can be ascribed to climatic change. For mean annual, summer, and winter discharge, as well as for the 75th, 90th, 95th, and 99th percentiles of daily discharge, we found no significant trends. Upward trends were found for mean annual, summer, and winter temperature, which forced significant upward trends in annual and winter $\mathrm{AE}$, although no significant trend in summer AE. For mean annual, summer, and winter precipitation no significant trends were simulated, although these parameters increased weakly. Hence, despite significantly increasing trends in $\mathrm{AE}$ over the last 100 years, no significant discharge trend was noted due to the compensatory effect of the weak increasing trend in precipitation.

4.4 Relative contributions of climate and land use change to changes in discharge

The results described in Sects. 4.1 to 4.3 show an increase in mean discharge and flood frequency between the natural reference state and the last millennium, with a further increase in the 20th Century. Given that the simulated increase in mean discharge mainly took place in the summer, that precipitation shows no trend over the last 1000 years, and that the intensity of large precipitation events was higher in 4000-3000 BP, we attribute the increase in mean discharge and high-flow events to a large extent to changes in land use (lower evapotranspiration due to decreased forested area). However, comparing the 20th Century results to those of the 19th Century, it appears that a significant increase in precipitation has become the dominant mechanism, since the observed reforestation over that period should theoretically have led to decreased discharge. To test this theory we carried out further hydrological simulations to delineate the effects of land use and climatic change.

For the period 4000-3000 BP we carried out a further simulation with STREAM, using one ECBilt-CLIO-VECODE ensemble member as climate input data, but using the land use and WHC maps of the 20th Century. Similarly, we ran a simulation with the 20th Century climate input data, but using the land use and WHC data for 4000-3000 BP. In this 
Table 4. Percentage change in mean annual $\left(Q_{\text {ann }}\right)$, summer $\left(Q_{\text {sum }}\right)$, and winter $\left(Q_{\text {win }}\right)$ discharge and various high-flow percentiles $\left(Q_{k}\right.$, $k=75,90,95,99)$ between 4000-3000 BP and the 20th Century AD (above), and between the 19th and 20th Centuries AD (below). The increase in discharge and high-flow magnitude between the period 4000-3000 BP and the 20th Century AD is mainly due to changes in land use. However, the increase in discharge and high-flow magnitude between the 19th and 20th Centuries AD is due to climatic change (mainly increased mean winter precipitation and increased precipitation intensity).

\begin{tabular}{lccccccc}
\hline & $Q_{\text {ann }}$ & $Q_{\text {sum }}$ & $Q_{\text {win }}$ & $Q_{75}$ & $Q_{90}$ & $Q_{95}$ & $Q_{99}$ \\
\hline \multicolumn{7}{l}{ Percentage change between 4000-3000 BP and 20th Century AD } \\
\hline Climate and land use & +12.5 & +28.8 & +7.7 & +11.3 & +7.1 & +5.6 & +4.1 \\
Climate only & - & +0.7 & -0.1 & -0.4 & +0.6 & +0.1 & -0.6 \\
Land use only & +12.4 & +28.1 & +7.8 & +11.7 & +6.6 & +5.5 & +4.8 \\
\hline Percentage change between 19th Century & AD and 20th Century AD & & \\
\hline Climate and land use & +3.5 & +0.3 & +4.6 & +4.3 & +2.9 & +3.2 & +4.0 \\
Climate only & +4.5 & +2.2 & +5.4 & +5.5 & +3.7 & +3.7 & +4.5 \\
Land use only & -1.0 & -1.9 & -0.7 & -1.2 & -0.8 & -0.5 & -0.5 \\
\hline
\end{tabular}

way the effects of changes in climate and land use were delineated. Similarly, we ran STREAM using climate data of the 19th Century with land use data for the 20th Century, and vice versa.

The results of these simulations (Table 4) show that the change in climatic conditions between 4000-3000 BP and the 20th Century has had almost no effect on discharge; almost all of the change on this timescale can be attributed to large-scale changes in land use (mainly a large decrease in forest at the expense of agricultural and urban land). The results of our sensitivity analysis show that changes in WHC have very little effect on either mean discharge or flood frequency, and hence we can attribute the increases to the significant reduction in $\mathrm{AE}$ which occurred as a direct result of deforestation. An examination of the changes in discharge characteristics between the 19th and 20th Centuries reveals the opposite pattern. As expected, the increased crop factor (due to reforestation) between these two time-periods means that the effect of land use change alone is to force a slight reduction in mean discharge and high-flow magnitude. However, the increase in precipitation (mean and intensity) between these two time-periods has overwhelmed the land use forcing, leading to increased discharge magnitudes, especially in the winter half-year (due to a relatively large increase in winter precipitation), and increased magnitude of high-flow events (due to increased precipitation intensity and increased winter half-year antecedent soil moisture).

\section{Discussion}

\subsection{Effects of land use change on discharge}

Our results are in agreement with those of recent studies on the effects of land use change on Meuse discharge. Tu (2006) investigated the observed discharge characteristics of the Meuse for the period 1912-2000, and found the effects of land use change to be marginal or statistically undetectable. Ashagrie et al. (2006) used the HBV model to simulate changes in Meuse discharge over the 20th Century, and concluded that the observed change in land use did not have a significant effect on discharge. Although we did not simulate changes in land use within the 20th Century, we see that the effect of land use change in the 20th Century in relation to the 19th Century is minor. On this timescale the changes in land use were relatively small and worked in a compensatory fashion in terms of their effects on AE, since the crop factor associated with forest is high, whereas that associated with urban areas is low.

Whilst land use change has not greatly influenced discharge over the last century, our results show that on a longer timescale the large-scale deforestation of the basin has led to significant increases in mean discharge and flood frequency. It is now widely accepted that forests can cause a reduction in mean discharge, especially during the summer half-year (Calder, 1993). The results of paired catchment studies in temperate zones have established strong links between deforestation and increasing mean discharge, and vice versa (Andréassian, 2004; Bosch and Hewlett, 1982; Hornbeck et al., 1993; Sahin and Hall, 1996). In single basin studies, large increases in discharge due to deforestation, or decreases due to reforestation, have been noted in Europe (Gallart and Llorens, 2004; Keesstra, 2006), Africa (Mahe et al., 2005; Scott et al., 2005), North America (Trimble et al., 1987), and South America (Costa et al., 2003; Iroumé et al., 2005). Various modelling studies of European streamflow have simulated significant changes in response to land use change (Bultot et al., 1990; Klöcking and Hamberlandt, 2002; Wegehenkel, 2002). Two of the most important factors affecting discharge via land use change are: (a) alterations in evapotranspiration totals (Calder, 1993; Hornbeck et al., 1993; 
Keesstra, 2006; Robinson et al., 2003) due to changes in leaf area, stomatal response, and interception; and (b) changes in soil water holding characteristics (Cosandey et al., 2005; Mahe et al., 2005); in our model the discharge effects of land use change can be mainly ascribed to changes in $\mathrm{AE}$, since the model is fairly insensitive to changes in WHC.

The effect of deforestation on high-flow events is more debated (EEA, 2001). In a review of 113 paired catchments, Andréassian (2004) found that flood volumes and peak-flows could increase after deforestation, but that the response was much more varied in time and space than for mean discharge. Nevertheless, large-scale deforestation has led to increased peak-flows around the globe (Brown et al., 2005; Gentry and Parody, 1980; Jones, 2000; Mahe et al., 2005), whilst reforestation has led to significant reductions in flood peaks (Fahey, 1994; Robinson et al., 1991). In our simulations, largescale deforestation led to increased flood frequency due to significant decreases in AE; this decrease in AE has both a direct effect due to increased surplus water availability, and an indirect effect due to earlier soil saturation.

5.2 Comparison of simulation results with proxy and historical data

In order to validate the results of our model for the late Holocene, we compared our findings with qualitative results based on multi-proxy data. Simulated mean summer and winter temperatures are in reasonable agreement with multi-proxy reconstructions of regional temperature for the late Holocene, which show a gradual decrease in temperature (especially in summer) (Bohncke et al., 1987; Goosse et al., 2006; Zagwijn, 1994). Proxy data on late Holocene precipitation change in the region are scarce, but suggest a slight increase in precipitation in the last millennium compared to the period 4000-3000 BP (Bohncke and Vandenberghe, 1991; Van Geel et al., 1996), though they give no indication of seasonal changes. Whilst these proxy data are very limited in detail, their main trends are in agreement with our results.

The qualitative results of multi-proxy studies on late Holocene Meuse discharge are in agreement with our conclusion of increasing mean discharge and high-flows. Berendsen and Stouthamer (2001) suggest that an increase in meander wavelengths in the Rhine-Meuse delta after ca. 2800 BP may be indicative of increased bankfull discharge in both rivers. Furthermore, they postulate that an increase in flood frequency may have occurred somewhere between 3000$2000 \mathrm{BP}$, as attested by an increase in avulsion frequency and the reoccupation of residual channels by floodwaters (e.g. Hofstede et al., 1989). De Moor (2007) states that the increasing thickness of fining-up sequences in the fluvial deposits of the Geul (Meuse tributary) could represent an increase in bankfull discharge due to deforestation since Roman times. Zagwijn (1986) suggests that a reduction of forested area in the Netherlands, especially since Roman times, led to a reduction in evapotranspiration, and consequently increased discharge. Similarly, Bohncke and Vandenberghe (1991) derived qualitative estimates of changes in evapotranspiration, precipitation, and temperature in the Mark Basin (southern Netherlands) to suggest that discharge was higher at 1000-2000 AD than at 4000-3000 BP. Based on an examination of historically documented floods over the period 1000-2000 AD, WL (1994b) conclude that the frequency of high-flow events since 1911 appears to have been greater than in the preceding centuries. However, it should be stressed that the frequency of floods in the historical record may be underestimated due to the lack of systematic measurements.

\subsection{Uncertainties and limitations}

Our model experiment includes a number of limitations, the most important being those associated with database uncertainties: (1) the climate model has a low spatial resolution and simplified physics compared to GCMs. This makes it impossible to correctly simulate the regional details and variability of daily precipitation; (2) the downscaling of precipitation is carried out using a simple linear correction technique based on monthly correction factors. Leander and Buishand (2007) found it to be advantageous to correct also for the variability of 10-day precipitation amounts. However, given the long timescales involved in the palaeodischarge approach a more sophisticated downscaling method was found to be unfeasible; (3) the land use data represent only a generalised pattern of land use change over the last millennium; (4) the resolution used in STREAM means that only larger river networks can be delineated. The chosen resolution does, however, allow for the assessment of changes in long-term discharge trends at the basin-scale (Ward, 2007); and those associated with physical process uncertainties: (1) the Thornthwaite \& Mather equation (1957) for AE is highly simplified; (2) the impact of anthropogenic water extraction and canalisation is not fully accounted for; (3) STREAM (and indeed any hydrological model), cannot fully describe the hydrological processes within the basin, and especially the groundwater and soil water processes are overly simplified. Hence it is difficult to assess the effects of changing soil characteristics on Meuse discharge, although changes in soil water holding capacity have been estimated.

These limitations inevitably introduce uncertainties in our results, and hence they should be used with caution. The discharge results should not be taken as exact figures for each period studied, but rather they give an indication of the main trends in mean discharge and flood frequency over the late Holocene, and can be used to examine relative changes between the time-slices studied. Similarly, the land use data do not represent the exact situation per century, but give an indication of the trend in land use change over the last millennium, and hence allow for an investigation of the sensitivity of the hydrological system to those changes. 
Despite these limitations, the calibration and validation of the model was successful for annual, monthly and daily discharge characteristics. Furthermore, the climate and discharge results are in agreement with the general trends inferred from the limited local and regional multi-proxy data. One of the major advantages of our approach is that we were able to perform millennial-scale simulations in ensemble mode, with multiple land use scenarios, which would not have been feasible with a full GCM.

\section{Conclusions}

According to our simulations the mean discharge, flood frequency, and flood magnitudes of the Meuse river were significantly greater in the last millennium than in the period 4000$3000 \mathrm{BP}$, as was the variability of mean annual discharge. The mean annual discharge increased by $6.6 \%$ between these time-slices; the most marked increase occurred in the summer half-year $(+21.6 \%)$. The recurrence time of large highflow events $\left(Q>3000 \mathrm{~m}^{3} \mathrm{~s}^{-1}\right)$ decreased from 77 years in the period 4000-3000 BP, to 65 years in 1000-2000 AD. On this timescale these increases can be almost fully attributed to changes in land use, and namely decreased evapotranspiration as a result of the large-scale deforestation of the basin. On a millennial timescale climatic change has had an insignificant effect on late Holocene Meuse discharge.

However, between the 19th and 20th Centuries climate change has overwhelmed land use change as the most important mechanism. Although evapotranspiration was higher in the 20th Century than in the 19th Century (due to reforestation and increased temperature), the mean discharge was greater in the 20th Century than during any preceding century, and $2.5 \%$ greater than in the 19th Century. The oc- currence of large high-flows $\left(Q>3000 \mathrm{~m}^{3} \mathrm{~s}^{-1}\right)$ was almost twice as frequent during the 20th Century as during the natural reference period 4000-3000 BP. Mean discharge and flood frequency were also greater in the 20th Century than in the period 1000-1900 AD, although the discharge and flood frequency in the latter period were still greater than in the natural reference period 4000-3000 BP. The increases in mean discharge and flood frequency in the 20th Century are the result of a strong increase in annual and winter precipitation compared to the preceding centuries, probably related to anthropogenic climate change. The effect of land use change alone between the 19th and 20th Centuries was to force a slight decrease in mean discharge and flood frequency, but these decreases were more than compensated for by increased precipitation in the 20th Century.

Many basins in western Europe have experienced similar changes in land use as a result of human activities during the late Holocene, and similar land use changes have occurred at different times throughout the mid-latitudes. The results of this study suggest that more research is needed to examine the potential contribution of land use management to flood mitigation in these regions. Theoretically, large-scale reforestation may offer protection against increased flooding in basins with a similar hydrological setting to the Meuse. However, in many basins space is at a premium, and largescale reforestation is not a viable option. Therefore, further experiments are needed to assess the relative effects of limited reforestation in the coming century, in combination with projected climate change scenarios. Since our model has been validated against (limited) multi-proxy data on a millennial timescale, and for large environmental changes, it forms a useful tool for such assessments. 


\section{Appendix A}

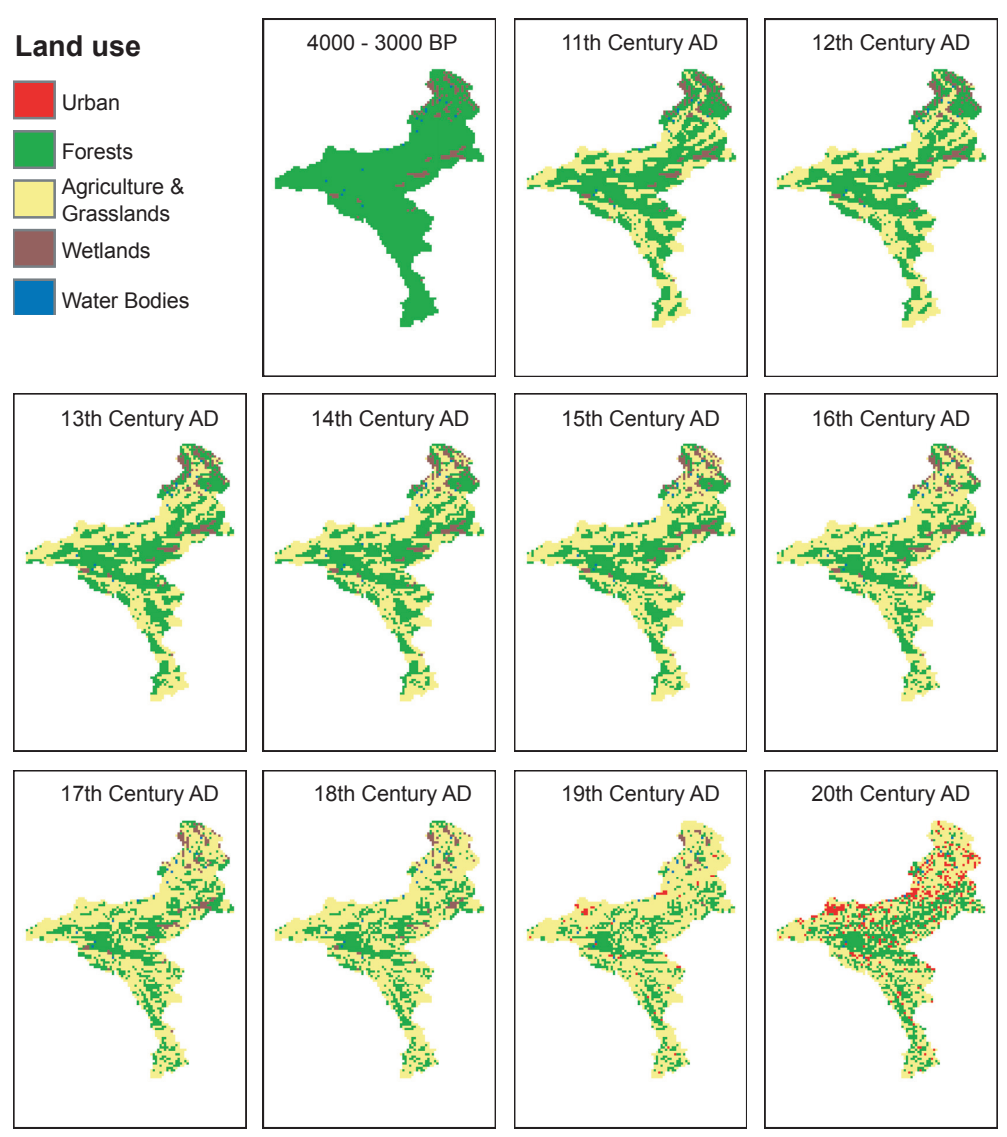

Fig. A1. Reconstructed Meuse basin land use maps for the late Holocene, showing the large decrease in forested area between 4000-3000 BP and 1000-2000 AD. In the 20th Century AD some reforestation has occurred. The maps are based on CORINE data, census data, historical records, and pollen analyses.

\section{Appendix B}

Table B1. Results of sensitivity analysis, obtained by running the STREAM model with one climate ensemble member for the period 1961-2000, and adjusting individual calibration parameters by $\pm 10 \%$ and $\pm 50 \%$. The correlation between the mean monthly values of each simulation and the observed values is given ( $r$ and N\&S). The model is sensitive to changes in crop factor, relatively insensitive to changes in soil water holding capacity (WHC) and slope (C), and very insensitive to changes in other parameters.

\begin{tabular}{lccccc}
\hline Discharge scenario & $r$ & N\&S & $Q_{\text {ann }}\left(\mathrm{m}^{3} \mathrm{~s}^{-1}\right)$ & $Q_{10}\left(\mathrm{~m}^{3} \mathrm{~s}^{-1}\right)$ & $Q_{90}\left(\mathrm{~m}^{3} \mathrm{~s}^{-1}\right)$ \\
\hline Borgharen observed & N/A & N/A & 275.1 & 61.0 & 625.0 \\
Borgharen simulated & 0.97 & 0.94 & 274.1 & 57.9 & 613.3 \\
Crop factor-10\% & 0.96 & 0.90 & 300.7 & 70.0 & 645.9 \\
Crop factor+10\% & 0.97 & 0.92 & 251.7 & 48.7 & 586.4 \\
WHC-10\% & 0.97 & 0.93 & 277.0 & 59.4 & 618.4 \\
WHC+10\% & 0.97 & 0.95 & 271.5 & 56.8 & 608.7 \\
C-10\% & 0.97 & 0.94 & 274.1 & 54.0 & 617.4 \\
C+10\% & 0.97 & 0.94 & 274.1 & 61.4 & 610.4 \\
Crop factor-50\% & 0.89 & -0.57 & 445.2 & 150.3 & 812.8 \\
Crop factor+50\% & 0.98 & 0.18 & 148.9 & 18.5 & 406.3 \\
WHC-50\% & 0.95 & 0.88 & 292.6 & 68.3 & 643.0 \\
WHC+50\% & 0.99 & 0.95 & 253.8 & 50.4 & 577.0 \\
C=1 & 0.97 & 0.94 & 274.1 & 49.4 & 622.1 \\
C+50\% & 0.95 & 0.90 & 274.3 & 79.4 & 597.9 \\
\hline
\end{tabular}


Acknowledgements. This research project was carried out in the framework of the Dutch National Research Programme "Climate changes Spatial Planning" (www.klimaatvoorruimte.nl). We would like to thank M. de Wit for the provision of numerous datasets, and for reviewing an earlier version of the manuscript. We also thank M. Sivapalan, D. Labat, and an anonymous reviewer for their useful comments, which helped to improve the paper.

Edited by: M. Sivapalan

\section{References}

Aerts, J. C. J. H. and Bouwer, L. M.: STREAM Krishna. A hydrological model for the Krishna River in India, RIKZ/Coastal Zone Management Centre, The Hague, The Netherlands, www.geo.vu. nl/users/ivmstream/public/aerts\&bouwer2002a.pdf, 2002.

Aerts, J. C. J. H., Kriek, M., and Schepel, M.: STREAM (Spatial Tools for River Basins and Environment and Analysis of Management Options): Set Up and Requirements, Phys. Chem. Earth B. 24(6), 591-595, 1999.

Aerts, J. C. J. H., Renssen, H., Ward, P. J., De Moel, H., Odada, E., Bouwer, L. M., and Goosse, H.: Sensitivity of global river discharges under Holocene and future climate conditions, Geophys. Res. Lett., 33, L19401, doi:10.1029/2006GL027493, 2006.

Andréassian, V.: Waters and forests: from historical controversy to scientific debate, J. Hydrol., 291, 1-27, doi:10.1016/j.jhydrol.2003.12.015, 2004.

Ashagrie, A. G., De Laat, P. J. M., De Wit, M. J. M., Tu, M., and Uhlenbrook, S.: Detecting the influence of land use changes on discharges and floods in the Meuse River Basin - the predictive power of a ninety-year rainfall-runoff relation?, Hydrol. Earth Syst. Sci., 10, 691-701, 2006,

http://www.hydrol-earth-syst-sci.net/10/691/2006/.

Berendsen, H. J. A. and Stouthamer, E.: Palaeogeographic development of the Rhine-Meuse delta, The Netherlands, Koninklijke Van Gorcum, Assen, The Netherlands, 2001.

Berger, H. E. J.: Flow Forecasting for the River Meuse, Ph.D thesis, Technische Universiteit Delft, Delft, The Netherlands, 1992.

Bohncke, S. J. P. and Vandenberghe, J.: Palaeohydrological development in the Southern Netherlands during the last 15000 years, in: Temperate palaeohydrology, edited by: Starkel, L., Gregory, K. J., and Thornes, J. B., John Wiley \& Sons, Chichester, U.K, 253-281, 1991.

Bohncke, S. J. P., Vandenberghe, J., Coope, R., and Reiling, R.: Geomorphology and palaeoecology of the Mark valley (southern Netherlands), II Palaeoecology and climate during the Weichselian Late Glacial, Boreas, 16, 69-85, 1987.

Booij, M. J.: Appropriate modelling of climate change impacts on river flooding, Ph.D thesis, Universiteit Twente, The Netherlands, 2002.

Booij, M. J.: Impact of climate change on river flooding assessed with different spatial model resolutions, J. Hydrol., 303(1-4), 176-198, doi:10.1016/j.jhydrol.2004.07.013, 2005.

Bosch, J. M. and Hewlett, J. D.: A review of catchment experiments to determine the effect of vegetation changes on water yield evaporation, J. Hydrol., 55, 3-23, 1982.

Bouwer, L. M., Vermaat, J. E., and Aerts, J. C. J. H.: Winter atmospheric circulation and river discharge in northwest Europe,
Geophys. Res. Lett., 33, L06403, doi:10.1029/2005GL025548, 2006.

Brovkin, V., Bendtsen, J., Claussen, M., Ganopolski, A., Kubatzki, C., Petoukhov, V., and Andreev, A.: Carbon cycle, vegetation, and climate dynamics in the Holocene: Experiments with the CLIMBER-2 model, Global Biogeochem. Cy., 16(4), 1139, doi:10.1029/2001GB001662, 2002.

Brovkin, V., Claussen, M., Driesschaert, E., Fichefet, T., Kicklighter, D., Loutre, M.-F., Matthews, H. D., Ramankutty, N., Schaeffer, M., and Sokolov, A.: Biogeophysical effects of historical land cover changes simulated by six Earth system models of intermediate complexity, Clim. Dynam., 26, 587-600, doi:10.1007/s00382-005-0092-6, 2006.

Brown, A. E., Zhang, L., McMahon, T. A., Western, A. W., and Vertessy, R.: A review of paired catchment studies for determining changes in water yield resulting from alterations in vegetation, J. Hydrol., 310, 28-61, doi:10.1016/j.jhydrol.2004.12.010, 2005.

Bultot, F., Coppens, A., Dupriez, G. L., Gellens, D., and Meulenberghs, F.: Repercussions of $\mathrm{a} \mathrm{CO}_{2}$ doubling on the water cycle and on the water balance - A case study for Belgium, J. Hydrol., 99(3-4), 319-347, 1988.

Bultot, F., Dupriez, G. L., and Gellens, G.: Simulation of land use changes and impacts on the water balance - case study for Belgium, J. Hydrol., 114, 327-348, 1990.

Bunnik, F. P. M.: Pollenanalytische Ergebnisse zur Vegetationsund Land-wirtschaftsgeschichte der Jülicher Lößbörde von der Bronzezeit bis in die frühe Neuzeit, Bonner Jahrbücher, 195, 313-349, 1995.

Calder, I. R.: Hydrologic effects of land use change, in: Handbook of Hydrology, edited by: Maidment, D. R., McGraw-Hill Inc., New York, 13.1-13.50, 1993.

Coe, M. T. and Harrison, S. P.: The water balance of northern Africa during the Mid-Holocene: an evaluation of the 6 ka BP PMIP simulations, Clim. Dynam., 19, 155-166, 2002.

Cosandey, C., Andréassian, V., Martin, C., Didon-Lescot, J. F., Lavabre, J., Folton, N., Mathys, N., and Richard, D.: The hydrological impact of the mediterranean forest: a review of French research, J. Hydrol., 301, 235-249, 2005.

Costa, M. H., Botta, A., and Cardille, J. A.: Effects of largescale changes in land cover on the discharge of the Tocantins River, Southeastern Amazonia, J. Hydrol., 283, 206-217, doi:10.1016/S0022-1694(03)00267-1, 2003.

De Moor, J. J. W.: Human impact on Holocene catchment development and fluvial processes - the Geul River catchment, SE Netherlands, Ph.D thesis, Vrije Universiteit Amsterdam, Amsterdam, The Netherlands, 2007.

De Wit, M., Warmerdam, P., Torfs, P., Uijlenhout, R., Roulin, E., Cheymol, A., Van Deursen, W., Van Walsum, P., Ververs, M., Kwadijk, J., and Buiteveld, H.: Effect of climate change on the hydrology of the river Meuse. Dutch National Research Programme on Global Air Pollution and Climate Change, Report number 410.200.090, RIVM, Bilthoven, The Netherlands, 2001.

De Wit, M. J. M., Van den Hurk, B., Warmerdam, P. M. M., Torfs, P. J. J. F., Roulin, E., and Van Deursen, W. P. A.: Impact of climate change on low-flows in the river Meuse, Climatic Change, 82(34), 1573-1480, doi:10.1007/s10584-006-9195-2, 2007.

Dutoo, D.: Onderzoeksproject Watersnood Maas. Het areaal onder bos in het Franse maasbekken van 1908 tot 1988, Universiteit 
Gent, Gent, Belgium, 1994.

EEA: Sustainable water use in Europe. Part 3: Extreme hydrological events: floods and droughts, Environmental issue report No. 21, EEA, Copenhagen, Denmark, http://reports.eea.europa. eu/Environmental_Issues_No_21/en, 2001.

Fahey, B.: The effect of plantation forestry on water yield in New Zealand, New Zealand Forestry, 39(3), 18-23, 1994.

FAO: Digital Soil Map of the World (DSMW) Version 3.6 (CDROM), Land and Water Development Division, FAO, Rome, Italy, 2003.

Gallart, F. and Llorens, P.: Observations on land cover changes and water resources in the headwaters of the Ebro catchment, Iberian Peninsula, Phys. Chem. Earth A/B/C, 29, 769-773, 2004.

Gellens, D. and Roulin, E.: Streamflow response of Belgian catchments to IPCC climate change scenarios, J. Hydrol., 210(1-4), 242-258, 1998.

Gentry, A. H. and Parody, J. L.: Deforestation and increased flooding of the Upper Amazon, Science, 210, 1354-1356, 1980.

Goosse, H. and Fichefet, T.: Importance of ice-ocean interactions for the global ocean circulation: a model study, J. Geophys. Res.Oceans, 104(C10), 23 337-23 355, 1999.

Goosse, H., Renssen, H., Timmermann, A., and Bradley, R. S.: Internal and forced climate variability during the last millennium: a model-data comparison using ensemble simulations, Quaternary Sci. Rev., 24(12-13), 1345-1360, 2005.

Goosse, H., Arzel, O., Luterbacher, J., Mann, M. E., Renssen, H., Riedwyl, N., Timmermann, A., Xoplaki, E., and Wanner, H.: The origin of the European "Medieval Warm Period", Clim. Past, 2, 99-113, 2006,

http://www.clim-past.net/2/99/2006/.

Gotjé, W., Van Wayjen, M. C. A., and Van Geel, B.: A palynological study of a Holocene deposit from Grand-Bongard (HautesFagnes, Belgium), Geologie en Mijnbouw, 69, 227-241, 1990.

Henrard, D.: The Mesolithic of the Ourthe Basin: Landscape settlement and Neolithisation, L'anthropologie, 107, 615-644, 2003.

Hofstede, J. L. A., Berendsen, H. J. A., and Janssen, C. R.: Holocene palaeogeography and palaeoecology of the fluvial area near Maurik (Neder-Betuwe, The Netherlands), Geologie en Mijnbouw, 68, 409-419, 1989.

Hornbeck, J. W., Adams, M. B., Corbett, E. S., Verry, E. S., and Lynch, J. A.: Long-term impacts of forest treatment on water yield: a summary for Northeastern USA, J. Hydrol., 150, 323343, 1993.

Iroumé, A., Huber, A., and Schulz, K.: Summer flows in experimental catchments with different forest covers, Chile, J. Hydrol., 300, 300-313, doi:10.1016/j.jhydrol.2004.06.014, 2005.

Jones, J. A.: Hydrologic processes and peak discharge response to forest removal, regrowth, and roads in 10 small experimental basins, western Cascades, Oregon, Water Resour. Res., 36(9), 2621-2642, 2000.

Keesstra, S. D.: The effects of natural reforestation on the hydrology, river morphology and sediment budget of the Dragonja River catchment, SW Slovenia, Ph.D thesis, Vrije Universiteit Amsterdam, Amsterdam, The Netherlands, 2006.

Klein Tank, A. M. G., Wijngaard, J. B., Können, G. P., Böhm, R., Demarée, G., Gocheva, A., Mileta, M., Pashiardis, S., Hejkrlik, L., Kern-Hansen, C., Heino, R., Bessemoulin, P., MüllerWestermeier, G., Tzanakou, M., Szalai, S., Pálsdóttir, T., Fitzgerald, D., Rubin, S., Capaldo, M., Maugeri, M., Leitass, A., Bukan- tis, A., Aberfeld, R., Van Engelen, A. F. V., Forland, E., Mietus, M., Coelho, F., Mares, C., Razuvaev, V., Nieplova, E., Cegnar, T., Antonio López, J., Dahlström, B., Moberg, A., Kirchhofer, W., Ceylan, A., Pachaliuk, O., Alexander, O. V., and Petrovic, P.: Daily dataset of 20th-century surface air temperature and precipitation series for the European Climate Assessment, Int. J. Climatol., 22(12), 1441-1453, 2002.

Klöcking, B. and Haberlandt, U.: Impact of land use changes on water dynamics - a case study in temperate meso and macro scale river basins, Phys. Chem. Earth A/B/C, 27(9), 619-629, 2002.

Knol, W. C., Kramer, H., and Gijsbertse, H.: Historisch grondgebruik Nederland: een landelijke reconstructie van het grondgebruik rond 1900, Alterra report 573, Alterra, Wageningen, The Netherlands, http://library.wur.nl/wasp/bestanden/ LUWPUBRD_00328279_A502_001.pdf, 2004.

Kwadijk, J. C. J.: The impact of climate change on the discharge of the River Rhine, Ph.D thesis, Universiteit Utrecht, Utrecht, The Netherlands, 1993.

Kwadijk, J. and Rotmans, J.: The impact of climate change on the River Rhine: a scenario study, Climatic Change, 30, 397-425, 1995.

Leander, R. and Buishand, T. A.: Resampling of regional climate model output for the simulation of extreme river flows, J. Hydrol., 332, 487-496, doi:10.1016/j.jhydrol.2006.08.006, 2007.

Leander, R., Buishand, A., Aalders, P., and De Wit, M.: Estimation of extreme floods of the river Meuse using a stochastic weather generator and a rainfall-runoff model, Hydrol. Sci. J., 50(6), 1089-1103, 2005.

Mahe, G., Paturel, J.-E., Servat, E., Conway, D., and Dezetter, A.: The impact of land use change on soil water holding capacity and river flow modelling in the Nakambe River, Burkina-Faso, J. Hydrol., 300, 33-43, 2005.

Matthews, H. D., Weaver, A. J., Eby, M., and Meissner, K. J.: Radiative forcing of climate by historical land cover change, Geophys. Res. Lett., 30(2), 1055, doi:10.1029/2002GL016098, 2003.

Middelkoop, H. and Parmet, B.: Assessment of the impact of climate change on peak flows in the Netherlands - a matter of scale, in: Proceedings of the second international conference on climate and water, edited by: Lemellä, R. and Helenius, N., Helsinki University of Technology, Espoo, Finland, 20-33, 1998.

Mitchell, T. D. and Jones, P. D.: An improved method of constructing a database of monthly climate observations and associated high-resolution grids, Int. J. Climatol., 25, 693-712, 2005.

Opsteegh, J. D., Haarsma, R. J., Selten, F. M., and Kattenberg, A.: ECBILT: a dynamic alternative to mixed boundary conditions in ocean models, Tellus, 50A, 348-367, 1998.

Pfister, L., Humbert, J., and Hoffmann, L.: Recent trends in rainfallrunoff characteristics in the Alzette river basin, Luxembourg, Climatic Change, 45, 323-337, 2000.

Pfister, L., Kwadijk, J., Musy, A., Bronstert, A., and Hoffmann, L.: Climate change, land use change and runoff prediction in the Rhine-Meuse basins, River Res. Appl., 20, 229-241, 2004.

Renssen, H., Goosse, H., Fichefet, T., Brovkin, V., Driesschaert, E., and Wolk, F.: Simulating the Holocene climate evolution at northern high latitudes using a coupled atmosphere-sea-iceocean-vegetation model, Clim. Dynam., 24(1), 23-43, 2005.

Robinson, M., Gannon, B., and Schuch, M.: A comparison of the hydrology of moorland under natural conditions, agricultural use 
and forestry, Hydrol. Sci. J., 36, 565-577, 1991.

Robinson, M., Cognard-Plancq, A.-L., Cosandey, C., David, J., Durand, P., Fürhrer, H.-W., Hall, R., Hendriques, M. O., Marc, V., McCarthy, R., McDonnell, M., Martin, C., Nisbet, T., O’Dea, P., Rodgers, M., and Zollner, A.: Studies of the impact of forests on peak flows and baseflows: a European perspective, Forest Ecol. Manag., 186, 85-97, doi:10.1016/S0378-1127(03)00238X, 2003.

RWS Limburg/IWACO: Internationale ecologische verkenning Maas (EVIM). Historisch ecologische oriëntatie op het stroomgebied (fase 2a), Rijkswaterstaat Directie Limburg, Afdeling Integraal Waterbeleid, Maastricht, The Netherlands, 2000.

Sahin, V. and Hall, M. J.: The effects of afforestation and deforestation on water yields, J. Hydrol., 178, 293-309, 1996.

Scott, D. F., Bruijnzeel, L. A., and Mackensen, J.: The hydrological and soil impacts of forestation in the tropics, in: Forests, water and people in the humid tropics, edited by: Bonell, M. and Bruijnzeel, L. A., Cambridge University Press, Cambridge, U.K., 622-651, 2005.

Thornthwaite, C. W.: An approach toward a rational classification of climate, Geogr. Rev., 38, 55-94, 1948.

Thornthwaite, C. W. and Mather, J. R.: Instructions and tables for computing potential evapotranspiration and the water balance, Publications in Climatology, 10, 183-243, 1957.

Trimble, S. W., Weirich, F. H., and Hoag, B. L.: Reforestation and the reduction of water yield on the southern Piedmont since circa 1940, Water Resour. Res., 23, 425-437, 1987.

Tu, M.: Assessment of the effects of climate variability and land use change on the hydrology of the Meuse river basin. Ph.D thesis, Vrije Universiteit Amsterdam, Amsterdam, The Netherlands and UNESCO-IHE, Delft, The Netherlands, 2006.

Van Deursen, W.: MEUSEFLOW 2.1, Laagwaterstudies Maasstroomgebied. Report number RI-2988A, RIZA, Arnhem, The Netherlands, www.carthago.nl/Publications/ MeuseLaagwater.PDF, 2000.
Van Geel, B., Buurman, J., and Waterbolk, H. T.: Archaeological and palaeoecological indications of an abrupt climate change in The Netherlands, and evidence for climatological teleconnections around 2650 BP, J. Quaternary Sci., 11(6), 451-460, 1996.

Ward, P. J.: A coupled climate-hydrological model for Meuse palaeodischarge modeling: set-up and calibration. Technical report July 2007, Department of Palaeoclimatology and Geomorphology, Faculty of Earth and Life Sciences, Vrije Universiteit Amsterdam, Amsterdam, The Netherlands, http://ivm5.ivm.vu.nl/adaptation/project/files/File/ Documents/Report_Meusepalaeo_Methods.pdf, 2007.

Ward, P. J., Aerts, J. C. J. H., De Moel, H., and Renssen, H.: Verification of a coupled climate-hydrological model against Holocene palaeohydrological records, Global Planet. Change, 57, 283300, doi:10.1016/j.gloplacha.2006.12.002, 2007.

Ward, R. C. and Robinson, M.: Principles of hydrology, McGrawHill Book Company, London, UK, 1990.

Wegehenkel, M.: Estimating of impact of land use changes using the conceptual model THESEUS - a case study, Phys. Chem. Earth A/B/C, 27, 631-640, 2002.

WL: Onderzoek Watersnood Maas. Achtergrondrapport 1. Hydrolgie, Deel A + B. Onderzoeksproject Watersnood Maas, Het Belgische stroombekken. Waterloopkundig Laboratorium, Delft, The Netherlands, 1994a.

WL: Onderzoek Watersnood Maas. Deelrapport 4. Hydrologische aspecten, Waterloopkundig Laboratorium, Emmeloord, The Netherlands, 1994b.

Zagwijn, W. H.: Nederland in het Holoceen. Rijks Geologische Dienst, Haarlem, The Netherlands, 1986.

Zagwijn, W. H.: Reconstruction of climate change during the Holocene in western and central Europe based on pollen records of indicator species, Veg. Hist. Archaeobot., 3, 65-88, 1994. 